\title{
THE ROLE OF NURSES AND THE QUALITY OF HEALTH SERVICES WITH THE SATISFACTION OF BPJS PATIENTS IN JUNREJO PUSKESMAS BATU CITY
}

\author{
Restu Pamungkas ${ }^{1}$ Indasah $^{2}$, Koesnadi $^{3}$ \\ ${ }^{1}$ Magister of Public Health Program, Stikes Surya Mitra Husada Kediri, Indonesia \\ ${ }^{2,3}$ Lecturer of Magister of Public Health Program, Stikes Surya Mitra Husada Kediri, Indonesia \\ Corresponding author: Restu Pamungkas (restupamungkas212@gmail.com)
}

\begin{abstract}
Patient satisfaction is related to service quality. By knowing the level of patient satisfaction, hospital management can improve service quality. Patient satisfaction is considered as one of the most important quality dimensions and is the key to success in health organizations that is also affected by the role of nurses. The purpose of this study was to determine the effect of nurse roles and service quality on BPJS patient satisfaction. The research design used was cross sectional with questionnaire sheet instruments. The population of this study were 230 BPJS patients. 144 samples used random sampling techniques, while to determine the effect between variables used ordinal regression test with a significant level of 0.05. Based on the results of the study it was found that the role of good nurses was 64 (44.4\%) respondents and most of the good quality services were 88 $(61.1 \%)$ and satisfaction in the satisfied category was 124 (86.1\%). The results of the data analysis showed that there was an influence of the nurse's role factor on satisfaction. It was known that the Sig (2-tailed) value had 0.00 and the service quality factor had an effect on satisfaction, this was known as Sig (2-tailed) which had a number 0.049. The existence of a good role from nurses will improve service quality and will improve BPJS patient satisfaction.
\end{abstract}

Keywords: Nurse's role, service quality, satisfaction

Copyright (C) 2019 Stikes Surya Mitra Husada. All right reserved.

\section{INTRODUCTION}

Health centers as one of the health facilities are expected to be able to provide effective, efficient and affordable services in order to provide appropriate health information in health services and be able to grow community satisfaction and produce accurate data. Along with the increasing public awareness about the importance of quality, it is necessary to improve the quality of health services oriented to patient satisfaction, which means trying to provide the best service and evaluate it based on the patient's glasses. Patients who enter the hospital with a set of expectations and desires, if the reality of experience during service is expected to lead to satisfaction and a customer loyalty that allows them to influence prospective new customers, conversely if their experience is lower than they expected it will lead to dissatisfaction ( Suryawati, 2004).

Patient satisfaction is related to service quality. By knowing the level of patient satisfaction, hospital management can improve service quality (Hospital Performance Indicators, Ministry of Health of the Republic of Indonesia in 2005). Patient satisfaction is considered as one of the most important quality dimensions and is the key to success in health organizations. Patient satisfaction can be examined in the context of the patient's overall experience with health organizations (Alrubaiee and Alkaa'ida, 2011) in Marzaweny, et al (2012).

Quality is the extent to which health services are provided in accordance with the Standard Operating Procedure or medical fixed procedures (Mukti, 2007). Quality service is characterized by doing the right things right. Bustami (2011) states that the quality of health services is the degree to which the needs of the community or individuals are met with health care in accordance with good 
professional standards by using resources fairly, efficiently, effectively in limitations safely and satisfying customers in accordance with good norms and ethics . Law No. 36 of 2009 concerning health emphasizes the importance of efforts to improve the quality of health services.

In addition to service quality, the role of nurses is also needed to improve patient satisfaction because nurses have more time with patients. According to Sudiharto (2007), which states that nurses are responsible for providing health education to families, especially to maintain families in caring for family members who have health problems. In addition, nurses can be a place to ask individuals, families and communities to solve health and nursing problems they face on a daily basis and can help provide a family way to overcome problems.

\section{METHODS}

The design of this study is the Cross Sectional approach. The population was 230 BPJS patients at the Junrejo Community Health Center. The total sample was 144 respondents using a simple random sampling technique. The dependent variable in this study is satisfaction and the independent variable is the role of the nurse, and quality. The instrument in this study used quitionare with ordinal regression statistical tests with a significance level of $p$ value $\leq 0.05$.

\section{RESULTS}

Table 1. Frequency distribution of nurse roles

\begin{tabular}{lll}
\hline Nurse & $\mathrm{n}$ & $\mathrm{f}(\%)$ \\
\hline Good & 64 & 44,4 \\
\hline Enough & 48 & 33,3 \\
Less & 32 & 22,1 \\
\hline Total & 144 & 100 \\
\hline
\end{tabular}

Source: 2018 research data

Based on the data obtained from the number of 144 respondents almost half of the respondents thought nurses nursing agency in the good category a number of 64 (44.4\%) respondents.

Table 2. Frequency distribution of service quality

\begin{tabular}{lll}
\hline Familly & $\mathrm{n}$ & $\mathrm{f}(\%)$ \\
\hline Good & 88 & 61,1 \\
\hline Enough & 25 & 17,4 \\
Less & 31 & 21,5 \\
\hline Total & 144 & 100 \\
\hline
\end{tabular}

Source: 2018 research data

Based on the data obtained from the number of 144 respondents almost half of the respondents thought the family nursing agency in the good category amounted to $88(61.1 \%)$ respondents. 
Table 3. Satisfaction

\begin{tabular}{lll}
\hline Behavior & $\mathrm{N}$ & $\mathrm{f}(\%)$ \\
\hline Statisfied & 124 & 86,1 \\
\hline Not satisfied & 20 & 13,9 \\
\hline Total & 144 & 100 \\
\hline
\end{tabular}

Source: 2018 research data

Based on the data obtained from the number of 144 respondents almost half of the respondents thought the behavior in the good category amounted to $124(86.1 \%)$ respondents.Tabel 4. Pseudo R-Square Test Results

Pseudo R-Square

\begin{tabular}{ll}
\hline Cox and Snell &, 140 \\
\hline Nagelkerke &, 254 \\
\hline McFadden &, 188 \\
\hline
\end{tabular}

The role factor of the nurse influences satisfaction. It is known that the Sig (2-tailed) value has 0.00 less than $\alpha=0.05$, which means that Ho is rejected and H1 is accepted. Service quality factors affect satisfaction, this is known as the Sig (2-tailed) value which has a number 0.049 smaller than $\alpha=0.05$, which means that Ho is rejected and $\mathrm{H} 1$ is accepted.

\section{DISCUSSION}

A. The Role of Nurses on Satisfaction of BPJS Patients in the Junrejo Community Health Center in Batu City.

The results of the research that has been done, get the results that out of 144 respondents, almost half of the respondents think the role of nurses is good, as many as 64 respondents $(44.4 \%)$. Whereas for nurses who felt sufficient, there were 48 respondents $(33.3 \%)$. and for those who feel less are 32 respondents $(22.2 \%)$.

According to Bagolz, (2010) Nurses are professions focused on the care of individuals, families, and communities so that they can achieve, maintain, or restore optimal health and quality of life from birth to death. According to Setiadi, (2011) Nurses are a profession that has an autonomous function that is defined as a professional function of nursing. The professional function is to help recognize and find immediate patient needs.

According to Sudiharto (2007), which states that nurses are responsible for providing health education to families, especially to maintain families in caring for family members who have health problems. In addition, nurses can be a place to ask individuals, families and communities to solve health and nursing problems they face on a daily basis and can help provide a family way to overcome problems.

The role of nurses as educators is considered important, because it can provide education directly to patients around stroke, ranging from prevention, treatment, therapy, and information about various things that patients should avoid during treatment. Nurses as nursing services and as facilitators are also very beneficial for patients. Patients can receive direct care such as blood pressure checks, weigh weight, which is very important for patients and make it easier for patients to control the development of the cure. In addition patients can also directly get answers to questions about the problems they are experiencing and get an easier solution.

Based on the results of the study found that the role of a good nurse is found in the role of nurses as educators and facilitators. Based on the questionnaire results obtained from 7 roles in nursing nursing agencies, starting from as educators, coordinators as executors of nursing services, supervisors, defenders, facilitators and researchers there are two roles that are mostly performed by 
nurses namely the role of nurses as educators and as facilitators. Nurses who carry out their role as educators who at any time provide education to patients about how to deal with their problems. In addition to the role of educators, nurses also carry out their role as facilitators where nurses provide an opportunity to ask something related to the patient's condition that is not yet understood by the patient and also provide solutions in dealing with problems faced by patients, by providing insight, providing problem solving and being able memandirikan patients in healthy behavior, so that those who are expected to experience health problems can be resolved properly.

Based on the results of the study it was found that the role of nurses was good at carrying out their responsibilities armed with the knowledge they had. The existence of patients who still feel lacking in receiving care from nurses needs to get attention and evaluation, considering nurses are the first person to receive patients when they start getting care and also always be with patients so they should be able to know all the patient's conditions with the treatment they are experiencing.

A. Service Quality Towards Satisfaction of BPJS Patients at the Junrejo Community Health Center in Batu City.

The results of the research that have been done in getting the results that out of 144 respondents most of them get good service quality 88 respondents $(61.1 \%)$. while for the quality of service that felt enough 25 respondents (17.4\%). And for the quality of service felt by 31 respondents $(21.5 \%)$.

Erwin Suryatama (2014) defines that quality is a picture of the direct characteristics of a product. Quality can be known in terms of shape, appearance, performance of a product, and can also be seen in terms of its function, as well as its aesthetic aspects. According to Chayatin (2012) defines quality or quality is conformity with market or consumer needs. Quality is the overall characteristics of goods or services that show their ability to satisfy consumer needs, both in the form of expressed needs and implied needs (Efendi, Ferry, 2012).

Improving service quality is the degree of providing services effectively and efficiently in accordance with professional standards, standard services that are carried out thoroughly in accordance with patient needs, utilizing appropriate technology and research results in developing health services so as to achieve optimal health degrees (Nursalam, 2014). The results of the study by Ali Mohammad Mosadeghrad (2014), quality in health care is the production of collaboration between patients and health care providers in a supportive environment. Personal factors from providers and patients, and factors related to health organizations, health systems, and the wider environment affect the quality of health services. Health quality can be improved by supporting visionary leadership, appropriate planning, education and training, availability of resources, effective resource management, employees and processes, and collaboration and collaboration between health care providers.

Satisfaction of BPJS Patients in the Junrejo Community Health Center in Batu CityFrom the results obtained on the satisfaction of BPJS patients in the city of junrejo puskesmas, satisfaction of patients who were satisfied with the role of nurses and the service quality of 124 respondents $(86.1 \%)$. And patients feel dissatisfied with the role of nurses and service quality is 20 (13.9\%)

Tjiptno (2010) in Nursalam (2014), satisfaction is a comparison between the quality of services that can be with desires, needs, and expectations. Satisfaction is defined as the level of one's feelings after comparing the performance (results) perceived by expectations, customer satisfaction is the main goal of excellent service so that each service apparatus is obliged to try to satisfy its customers (Drayanto and Ismanto Setyabudi, 2014).

From the discussion of the role of nurses and the quality of health services to the satisfaction of BPJS patients in the health center of Junrejo, Batu City is good and satisfied with the service and quality of services in the Junrejokota Batu Puskesmas. But the satisfaction felt by PBI and non PBI patients according to researchers has little difference because the PBI's economic status is below average and non PBI is above the average.

It is undeniable that the services provided by puskesmas are simple services compared to regional and private hospitals and services are mostly handled by nurses. So according to the researchers the satisfaction felt by PBI patients when treated by nurses or general practitioners has been very satisfied, but when non PBI patients are more satisfied to be cared for by general 
practitioners or specialists. And satisfaction with the facilities felt by PBI and non PBI patients is also different.

Relationship between nurse role and quality of health services with satisfaction of BPJS patient services Based on the results of the study, it was found that the nurse's role factor had an effect on satisfaction. This was known as the Sig (2-tailed) value which had 0.00 less than $\alpha=0.05$ which means Ho was rejected and $\mathrm{H} 1$ was accepted. Service quality factors affect satisfaction, this is known as the Sig (2-tailed) value which has a number 0.049 smaller than $\alpha=0.05$, which means that Ho is rejected and $\mathrm{H} 1$ is accepted.

Health centers as one of the health facilities are expected to be able to provide effective, efficient and affordable services in order to provide appropriate health information in health services and be able to grow community satisfaction and produce accurate data. Along with the increasing public awareness about the importance of quality, it is necessary to improve the quality of health services oriented to patient satisfaction, which means trying to provide the best service and evaluate it based on the patient's glasses. Patients who enter the hospital with a set of expectations and desires, if the reality of experience during service is expected to lead to satisfaction and a customer loyalty that allows them to influence prospective new customers, conversely if their experience is lower than they expected it will lead to dissatisfaction ( Suryawati, 2004).

Patient satisfaction is related to service quality. By knowing the level of patient satisfaction, hospital management can improve service quality (Hospital Performance Indicators, Ministry of Health of the Republic of Indonesia in 2005). Patient satisfaction is considered as one of the most important quality dimensions and is the key to success in health organizations. Patient satisfaction can be examined in the context of the patient's overall experience with health organizations (Alrubaiee and Alkaa'ida, 2011) in Marzaweny, et al (2012).

Quality is the extent to which health services are provided in accordance with the Standard Operating Procedure or medical fixed procedures (Mukti, 2007). Quality service is characterized by doing the right things right. Bustami (2011) states that the quality of health services is the degree to which the needs of the community or individuals are met with health care in accordance with good professional standards by using resources fairly, efficiently, effectively in limitations safely and satisfying customers in accordance with good norms and ethics . Law No. 36 of 2009 concerning health emphasizes the importance of efforts to improve the quality of health services.

This is in accordance with the results of research where it is found that the role of a good nurse and good quality service will produce good satisfaction.

\section{CONCLUSION}

1. BPJS patient satisfaction in Junrejo Batu City obtained results that out of 144 respondents, almost half of the respondents thought the role of nurses was good, namely as many as 64 respondents $(44.4 \%)$.

2. Quality of service to the satisfaction of BPJS patients in the city of Batu Junrejo The results of the research that has been done to get the results that out of 144 respondents most of them get good service quality 88 respondents $(61.1 \%)$.

3. BPJS patient satisfaction junrejo stone city From the results obtained get satisfied with the role of nurses and service quality 124 respondents $(86.1 \%)$.

4. There is an influence factor of nurse's role on satisfaction. It is known that the Sig (2-tailed) value has 0.00 and the service quality factor influences satisfaction, this is known as the Sig (2-tailed) value which has a number 0.049 .

\section{SUGGESTION}

1. For the community

For the community to know about the satisfaction that has been felt by fellow patients who visit the health center of the city of Junrejp Batu regarding the role of nurses and the quality of services that are carried out in the health center of the city of Junrejo Batu. 
2. For Research Land

For research land to further activate the role in providing facilities to the community in an effort to improve the quality of health care services at the Batu City junrejo health center

3. For further researchers

For the next researcher As a reference for further researchers to conduct more specific research on the provision of interventions with a nursing theory approach in an effort to increase satisfaction regarding the role of nurses and the quality of services in public health centers, hospitals.

4. For Health Agencies

For health agencies, especially nurses who are in the community health center or community to do excellent service quality so that patients who visit feel very satisfied with the services provided.

\section{REFERENCES}

Alamsyah, \& Muliawati. (2013). Pilar Dasar Ilmu Kesehatan Masyarakat. Yogyakarta: Nuha Medika.

Andi, \& Ari, R. (2011). Hubungan Mutu Pelayanan Kesehatan dengan Tingkat Kepuasan Pasien Jamkesmas di Instalasi Rawat Inap RSUD dr. Rasidin Kota Padang Tahun 2011. Skripsi: Universitas Andalas Padang.

Anjaryan, \& Diah, W. (2011). Kepuasan pasien rawat inap terhadap pelayanan perawat di RSUD Tugurejo Semarang. Tesis. Universitas Diponegoro semarang.

Arikunto, \& Suharsimi. (2012). Prosedur Penelitian Suatu Pendekatan Praktik (Edisi Revisi VI). Jakarta: Rineka Cipta. 2010. Prosedur Penelitian Suatu Praktik. Jakarta: Rineka Cipta.

Bustami. (2011). Penjamin Mutu Pelayanan Kesehatan dan Akseptabilitasnya. Jakarta: Erlangga. Daryanto, \& Ismanto. (2014). Konsumen dan Pelayanan Prima. Yogyakarta: Gava Medika.

Departemen Kesehatan RI. 2009. Undang- Undang Kesehatan Nomor 36 Tahun 2009. Jakarta: Depkes RI. 2008. Profil Kesehatan Indonesia. Jakarta: Depkes RI.

Depkes RI. (2009). Undang- Undang tentang Kesehatan Nomor 36 Tahun 2009. Jakarta: Depkes RI.

Dian, \& Ririn. (2011). Faktor- faktor yang berhubungan dengan kepuasan pasien terhadap pelayanan kepuasan pasien terhadap pelayanan kesehatan di Puskesmas Halmahera Kota Semarang Tahun 2011. Skripsi: Universitas Negeri Semarang.

Kepmenkes RI Nomor 128/Menkes/SK/II/2004. Kebijakan Dasar Pusat Kesehatan Puskesmas. Jakarta: Menkes RI. Nomor 828/Menkes/SK/IX/2008. Petunjuk Teknis Standart Pelayanan Minimal Bidang Kesehatan di kabupaten/Kota. Jakarta: Menkes RI. Nomor 029 Tahun 2012. Tarif Pelayanan Kesehatan bagi Peserta PT Askes ( Persero). Jakarta: Menkes RI.

Lupiyoadi, \& Hamdani. (2009). Manajemen Pemasaran Jasa (Edisi 2). Jakarta: Salemba Empat.

Mubarak, Iqbal, W., \& Chayati. (2012). Ilmu Kesehatan Masyakat. Jakarta: Salemba Medika.

Mukti, \& Ghufron, A. (2012). Strategi Terkini Peningkatan Mutu Pelayanan Kesehatan. Yogyakarta: PT. Karya Husada Mukti. 
Notoatmodjo, \& Soekidjo. (2010). Metodologi Penelitian Kesehatan Edisi Revisi.Jakarta: Rineka Cipta.

Nursalam. (2014). Manajemen Keperawatan Profesional Edisi 4. Jakarta: Salemba Medika.

Peraturan Menteri Kesehatan RI Nomor 71 Tahun 2013. Pelayanan Kesehatan pada Jaminan Kesehatan. Jakarta: Menkes RI. Nomor 75 Tahun 2014. Pusat Kesehatan Masyarakat. Jakarta: Menkes RI.

Pohan, \& Imbalo, S. (2011). Jaminan Mutu Pelayanan Kesehatan, Dasar- dasar Pengertian. Jakarta: Kesaint Blanc.

Prasetyawati, \& Eka, A. (2011). Ilmu Kesehatan Masyarakat Untuk Kebidanan Holistik. Yogyakarta: Nuha Medika.

Puskesmas Boyo. (2015). Profil Kesehatan Puskesmas Tambakboyo Tahun 2015. Ngawi Indonesia.

Sabarguna, Boy, S. (2008). Quality Assurance Pelayanan Rumah Sakit Edisi revisi. Jakarta: CV Sagung Seto.

Saputra, \& Diman, A. (2015). Hubungan mutu pelayanan BPJS kesehatan dengan kepuasan pasien di instalasi rawat inap kelas 2 RSU daerah Sekayu. Skripsi: RSUD Sekayu.

Saryono, \& Anggraeni, M., D. (2013). Metodologi Penelitian Kuantitatif dan Kualitatif dalam bidang Kesehatan. Yogyakarta: Nuha Medika.

Satianegara, Fais, M., \& Saleha, S. (2009). Buku Ajar Organisasi dan Manajemen Pelayanan Kesehatan Serta Kebidanan. Jakarta: Salemba Medika.

Sugiyono. (2010). Statistik Untuk Penelitian. Bandung: Alfabeta. 2010. Metodologi Penelitian Pendidikan. Bandung: Alfabeta.

Suryatama, \& Erwin. (2014). Aplikasi ISO Sebagai Standart Mutu. Jakarta: Kata Pena.

Suprapti, \& Endang. (2015). Menilik Layanan Kesehatan. (http://print.kompas.com). Kementrian Kesehatan Republik Indonesia. 2013. Pedoman Penyelenggaraan Puskesmas Mampu PONED. Jakarta: Menkes RI. 